\title{
Legal Process of Deposit Disputes in Commercial Bank
}

\author{
Hailing Wu \\ Department of Law \\ Hebei University of Engineering \\ Handan, China \\ 41080639@qq.com
}

\author{
Yanmei Huo \\ Department of Law \\ Hebei University of Engineering \\ Handan, China \\ zengmei1974@163.com
}

\begin{abstract}
Various kinds of deposit disputes constantly happened in social life. Due to different cognition, the processing of similar disputes in local courts varies greatly. Analyzing deposit disputes and following the appropriate legal principles for classified processing can unify cognition and judgment, so as to better protect interests of both depositors and commercial banks.
\end{abstract}

Keywords-deposit; disputes; legal process

\section{INTRODUCTION}

Deposits can be described as the most frequent credit activity between the public and the commercial bank. In daily life, various deposit disputes always arise. To analyze them from a legal perspective helps to distinguish between right and wrong, and to clarify the legal rights and obligations.

\section{NATURE OF THE DEPOSIT}

Deposits, judged from the legal nature, are debt payment. In British and American law, the nature of deposits and loans is not different, but the main roles are not the same. This relationship is based on claims and liabilities arising from the contract, the deposit Contractual Obligations. What the depositors lend and transfer is the right to use funds, retaining the ownership of funds. Banks are responsible for the possible damage to the interests of depositors. However, in Civil Law, deposits are considered to be consumer sustenance, but permitted consumer lending regulations. Depositors can be disposed of consumer sustenance, but return the same type and the same number of things when it's due. Currency deposits also have the nature of monetary investment and properties custody.

Deposit contract is practical contract (properties contract), which should be established by actual delivery of funds, that is to say the actual amount of money should be transferred to commercial banks and inventory should be completed. Deposit contract can not be established if the amount of money is not clear. As for the certificates of deposit--deposit receipt, deposit book or bank card, they are only a valid proof of commercial banks' taking the deposits. However, the presence or authenticity of certificates of deposit does not necessarily equate to the presence and authenticity of certificates of deposit, which affects only the allocation of the burden of proof.
The nature of the legal relationship of savings deposits is also the consumer legal relationship, as the depositors should be citizens. "Consumer Protection Law" also applies to the depositors when they accept the deposit services provided by the commercial bank, and enjoy the safety and security of consumers rights and other legal rights, while commercial banks should also fulfill the statutory obligations stipulated in "Consumer Protection Law". If the depositors' rights have been infringed, they may either accuse the bank of breach according to the contract claim, or ask the bank to be responsible for infringement based on "Consumer Protection Law". Of course, in the case of competing responsibilities, savings depositors can only choose one.

\section{LAW OF DEPOSIT DISPUTES}

Deposit disputes, in the form of certificates of deposit, can be divided into two types. The first type includes doubtful legal relationship of deposits, i.e, the certificates of deposit or deposit relationships are untrue; the second type is the disputes caused by deposits drawn by others although deposit relationship itself is real and effective. These two types, due to the different premise, are dealt with differently in the legal process.

\section{A. Deposit Disputes with Doubtful Legal Relationship Should Use "Double Truth" Principles}

Such disputes are caused by false deposit relationships. For example, a depositor actually deposits 50,000 yuan in the bank, but because of failures of bank staff there is another " 0 " in the amount, which becomes 500,000 yuan. When the bank realized the error the depositor denied, insisting on banks'cashing 500,000 yuan. In this case, the bank receipt is true, but the actual deposit is obviously different from it.

Such disputes can be triggered by unreal certificates of deposit. Take the following case as an example. Ye, the perpetrator, deceived Zou that as long as he deposits the money to a bank, he can get an added benefit of $1 \%$ besides the normal interest per month. Zou believed. In February 2005 Zou together with Ye deposited 2 million yuan to a bank. Qin, one of the bank staff, who was in collusion with Ye, gave Zou a pre-prepared false certificate of deposit and afterwards gave the real one to Ye. Ye withdrew 2,000,000 yuan the next day with the genuine certificate of deposit, and Qin gained 100,000 yuan. Subsequently Ye and Qin cheated others out of 8 million yuan in the same way. After it was 
exposed, Ye and Qin were respectively sentenced. Zou required the bank to pay 2 million yuan, but failed. Then he sued. In this case, Zou held the fake certificate of deposit, but he indeed deposited 2 million yuan into the bank, so the deposit relationships really existed.

According to Supreme Court's "Regulations on Dealing with Disputes of Deposits ", such disputes should follow the "double truth" principle. The authenticity of certificates of deposit and the deposit relationship should be both examined. In the case of real deposits, if commercial banks refused to pay the money they should put to the proof. Commercial banks shouldn't defend with the evidence that it does not match the record; while in the case of unreal certificates of deposit, depositors should put to the proof that the deposit relationship is real. If the authenticity of the deposit relationship is proved, the bank should pay the deposit and interest. That is what has been mentioned in the nature of deposits. The presence or authenticity of certificates of deposit does not necessarily equate to the presence and authenticity of certificates of deposit. It affects only the allocation of the burden of proof.

As to the previous two cases, in the former, the bank should put to the proof. Bank surveillance video can be the proof of the actual deposit amounted to 50,000 yuan. While in the latter, the depositor should prove that the deposit of 2,000,000 yuan was real. The criminal judgments of Ye and Qin are considered one of the best evidence.

\section{B. "Fault Liability" Principles Apply to the Deposit with True and Legal Relationship but Drawn by Others.}

In the case of real and effective deposit relationship, there are many disputes caused by others' illegal withdrawal in a variety of situations. The "others" may be the perpetrator, and may also be other interested parties. For example, in recent years, there are many fraudulent cases caused by ATM cloned cards. The perpetrator played tricks on the ATM, they stole depositor's bank card information and password by the use of storage devices with card reader and pinhole camera, and then forged bank cards so as to remove deposits. In another case, a company of agriculture machinery got a loan from a county branch of China Industrial and Commercial Bank with Wang's time certificate as mortgage. However, due to the lack of funds, without Wang's consent, the deposit was withdrawn only with a letter of introduction issued by the superiority. Wang repeatedly negotiated with the branch but failed. So he sued. One more example, Zhang's deposit was removed by fake ID. In May 2008, Zhang's 100,000 yuan passbook was lost in Wenchuan earthquake. In October reconstruction, Zhang reported the loss of ID card to the bank, only to be informed that the bankbook was removed in August when the loss was reported. Zhang sued, requiring banks to pay the deposit of 100,000 yuan and interest. The bank argued that the deposit had been removed, so they did not need to repay it. The bank also provided a copy of the loss reporting application form and a copy of ID card. Judicial technical evaluation reported that the signature of loss reporting application form was not
Zhang's handwriting, and the identity information was also false.

"Fault Liability" principles apply to such disputes. When there is evidence to show that commercial banks took a fault, the bank should be responsible for the compensation. In the first case mentioned above, the banking system couldn't guarantee the security of ATM as a place of business, resulting in the leakage of depositor's bank card information; while ATM technically flawed, as they can not effectively identify fake bank cards, and eventually undermined depositor's right to security deposits. In the second case, the bank obviously violated the regulations on early withdrawal of deposits in "Savings Management Regulations". The identification of Wang and the substitute was not required. The deposit was withdrawn only with a letter of introduction issued by the superiority. So the bank should bear all liability.

The third case is mainly about whether the bank's obligation of auditing the customer's identity is limited to the form or the authenticity. The author believes that although in 1997 People's Bank of China, in "Reply to the Handling of Issues Related to Deposit Loss Reporting Procedures ", stipulates that in the process of loss reporting the savings institutions are only responsible for reviewing the form of identification, they will not have to identify the authenticity of identity. But in June 2007, China people's Bank in conjunction with the Ministry of Public Security information Center has built the networking citizenship verification system. The national banking institutions, based on "Verification of Citizens Banking Financial Institutions Identity Information Requirements (trial) "(Silver Ban Fa [2007] No. 126) issued by the General Office of People's Bank of China, require in the process of bank accounts, payment and settlement, credit and access to 50,000 yuan or more, customers' identity information should be verified through networking citizenship verification system. Thus, the bank should audit the authenticity of customers' identity. In the third case, the bank did not strictly audit the identity of the person who reported the loss so the obligation of auditing was not fulfilled, which is the bank's fault. So the bank should pay for Zhang's deposit and interest.

However, if the depositor's certificates of deposit are lost or robbed, or the depositor leaked out the information of accounts and passwords, and the money is claimed by others before the loss is reported, the depositor should be responsible for it. For example, a lady's handbag, with bank cards, mobile phones and so on in it, is stolen. The thief uses her mobile phone to send messages to the number named as "husband", asking for the bank card password, and then successfully takes the deposit. There are many elderly people at home receiving the phonecalls from the so-called Public Security Bureau, the law court or the procuratorate. They are informed that their deposit accounts are used by criminals to launder money and commit crime. In a panic, they reveal the deposit account number and password, resulting in the loss of deposit money. In those cases, according to the "fault liability" principle, the depositor can only pay for their own fault. 


\section{REFERENCES}

[1] Anonymous, "Different judgments on similar disputes of stolen bank deposits” Rules of Law and Economy, April 2011.

[2] Peng Caihong, " Analysis on legal principles of disputes caused by false claim of deposits”, Zone Economy, January 2009.

[3] Wei Yanjun and Wang Guan, "Legal risk prevention of deposits disputes in commercial banks ”, Knowledge Economy, July 2011.

[4] Xie Gen, "Legal principle of disputes caused by false claim of deposits -- analysis of Wang's winning over Hexi branch of Bank of China in Nanjing in the lawsuit of savings contract disputes", Zhejiang Social Sciences, February 2013. 